Working Paper

Business Economic Series

WP. 14-03

ISSN 1989-8843
Instituto para el Desarrollo Empresarial. Universidad Carlos III de Madrid

C/ Madrid, 126

28903 Getafe Madrid (Spain)

FAX (34-91)6249607

\title{
Bank Competition, Borrower Competition and Interest Rates
}

\author{
Carlos Bellón ${ }^{1}$ \\ Universidad Carlos III de Madrid
}

\footnotetext{
${ }^{1}$ Department of Business Administration, Universidad Carlos III de Madrid. Calle Madrid, 126, Getafe, Madrid 28903, Spain, phone: +34 916-249-572, fax: +34 916-249-607, email: carlos.bellon@uc3m.es.
} 


\title{
Bank Competition, Borrower Competition and Interest Rates
}

\author{
Carlos Bellón*†
}

June 16, 2014

\begin{abstract}
The effect bank competition has on interest rates should depend on the fact that borrowers compete against each other. The borrowing rate of a firm affects its ability to compete in the industrial marketplace, and ultimately, its ability to repay its loans. Thus, competition amongst borrowers acts as a limit to the amount of rents financial oligopolists can extract. I find evidence that firms that operate within areas of limited bank competition face higher rates than their peers. I also identify an innovative control group that can be used in tests of bank market structure.
\end{abstract}

Keywords: Bank competition; Small business lending

JEL classification: D43, E43, G21

* Department of Business Administration, Universidad Carlos III de Madrid. Calle Madrid, 126, Getafe, Madrid 28903, Spain, phone: +34 916-249-572, fax: +34 916-249-607, email: carlos.bellon@uc3m.es.

${ }^{\dagger}$ I would like to thank Itay Goldstein, David Musto, Nicholas Souleles and Bilge Yilmaz for their invaluable guidance. I would also like to thank Nickolay Gantchev and seminar participants at the University of Pennsylvania (Wharton), The Federal Reserve Bank of Boston, CUNEF, IE Business School, IESE, Comisión Nacional del Mercado de Valores, Universidad Carlos III de Madrid, AIDEA Bicentenary Conference, the XXI Finance Forum in Segovia and the 2014 FIRS conference in Quebec. I gratefully acknowledge the financial support provided by the Fundación Ramón Areces and the Santander Finance Institute - Fundación UCEIF. 
Economic research has provided robust empirical evidence that more developed financial markets play a role in fostering economic growth ${ }^{1}$. Yet, what effect bank competition has on the commercial loan market remain a contested issue ${ }^{2}$ in academia.

My paper contributes to this debate by analyzing the effect bank competition has on the interest rate charged to Small and Medium Enterprises (SMEs). I propose that this effect should different for different kind of firms (in particular, those that compete within or across banking markets). I arrive at the conclusion that not all firms can be equally affected by the exercise of market power by oligopolistic banks, by taking into account a key characteristic of commercial lending markets often overlooked: the fact that borrowers compete against each other.

Once we consider this fact, it is easy to see that the rate at which a given firm can secure capital affects its ability to compete in the industrial marketplace, and ultimately, its ability to repay its loans. Thus, competition amongst borrowers acts as a limit to the amount of rents that financial oligopolists can successfully extract. Indeed, if industrial markets are interconnected then financial markets must be interconnected too. Accordingly, banking competition should be measured over industrial markets. With the relevant measure of financial competition being the number of banks "in range" of a given firm or its competitors.

This is both an important substantive issue (specially for economic policy) and helps design an econometric test that avoids some of the endogeneity issues plaguing the empirical literature on the study of banking market power. It is often difficult to discern whether a bank is simply exercising its market power or if there are unobserved bank and/or firm characteristics that lead to higher equilibrium interest rates or restricted access to finance. But my empirical setup controls for systematic variation between locations in which banking is competitive and those in which it is not.

\footnotetext{
${ }^{1}$ This literature dates back to at least Schumpeter (1912). Some more recent contributions are Rajan and Zingales (1998), King and Levine (1993) and Levine, Loayza and Beck (2000), amongst others.

${ }^{2}$ Surveys of the empirical literature find mixed evidence of the importance of bank competition. Weiss (1989), for example, finds significant (at the $5 \%$ level) positive association between interest rates and bank competition on only 21 of the 47 datasets it reviews. Gilbert (1984) finds that 32 out of 44 studies surveyed report some evidence of association between market structure and bank performance, with only 25 showing statistically significant associations.
} 
I achieve identification through the use of a difference-in-differences test that measures the differential effects of a change in bank competition (from more to less competitive banking markets) between firms that compete in wide geographical markets (the "control" group) and those whose competitors all lie within the area of influence of the banking market under study (the "treatment" group).

Using data on loan terms and banking and industrial markets from the Survey of Small Business Finances (SSBF), I find that, all else being equal, firms whose markets all lie within areas of limited bank competition are significantly overcharged for financing. This surcharge is on the order of 60 to 70 basis points, accounting for a third of the average spread over the prime rate (211 basis points, with a standard deviation of 14 basis points) in the sample, or $10 \%$ of the average interest rate $(6.56 \%)$.

These results confirm previous evidence of significant distortions in the commercial loan market created by lack of bank competition obtained by using different empirical strategies to my own (see, for example, Rice and Strahan (2010), Zarutskie (2006) or Cetorelli and Strahan (2006)). But also underscore the issue that different firms are affected by the structure of banking markets differently. From a methodological point of view, this paper identifies an innovative control group of firms that can be used to perform tests of the effect of bank market structure.

The key identifying condition in my methodology is that the only interaction between the level of competition in banking markets and the geographical span of industrial markets relevant for loan pricing is the exercise of market power (no omitted interactions). I assume that, after accounting for the usual determinants of interest rates, systematic differences between "treatment" and "control" groups (if any) are similar in competitive and non-competitive banking markets. If this assumption does not hold two alternative hypotheses could explain my results. First, there could be an unobserved risk or cost factor systematically higher only for firms whose markets all lie within areas where banking competition is limited. Second, if market power is indeed being exercised, some kind of friction (different from industrial market structure) could explain the higher 
interest rates that these firms experience. In Section V, I perform extensive robustness checks, discuss these alternative explanations at length and use the depth of information available in the Survey of Small Business Finances to perform additional tests that support the no omitted interactions assumption.

The remainder of the paper is organized as follows. Section I, reviews the related literature. Section II describes the new definition of relevant banking market that I will use in this paper. Section III presents an empirical strategy, based on the previous analysis, that will help isolate the effects of banking market power on the pricing of small business loans at the local level. Section IV describes the empirical tests performed and their results. Section V analyzes the robustness of these results, discuss the plausibility of the model's key identifying assumption and of its competing hypotheses. Section VI concludes.

\section{Literature Review}

Traditional banking literature looks at a banks' lending decision as a portfolio problem, taking the distribution of returns as exogenously given and ignoring the fact that loan performance depends on the actions of borrowers too. This papers fits within the growing strand of banking literature ( Boyd and De Nicolo (2005), and Martinez Miera and Repullo (2010), for example) that takes into account the actions of borrowers when analyzing the dynamics of the banking market.

My approach also contributes to an existing body of literature that looks at the identification problem in the empirical analysis of the effects of bank competition from a range of perspectives. One strand of literature, exemplified by Berger, Saunders, Scalise, and Udell (1998) and Sapienza (2002), uses exogenous changes in the level of competition to measure its effects in the banking market. Specifically, this literature uses bank-level data to measure how mergers affect banks' loan portfolios and therefore credit availability.

Another literature strand uses instrumental variables to help identify effects of competition in banking. Zarutskie (2006) looks at changes in banking regulation, such as the Riegle-Neal Interstate 
Banking and Branching Efficiency Act of 1994 and finds that an increase in competition reduces access to credit for young firms. Thus, confirming the model of Petersen and Rajan (1995). More in line with the variable of interest in this paper, Rice and Strahan (2010) use the Interstate Banking and Branching Efficiency Act of 1997 as an instrument to test how credit competition affect small firm financial decisions, and find that loosening branching restrictions leads to interest rate savings of 80 to 100 basis points. An effect that is confirmed by my own results, and in turn agrees with earlier work by Jayaratne and Strahan (1996), who study economic growth due to more efficient banking systems after pro-competitive intrastate branching reforms. Black and Strahan (2002) also use changes in regulation to both inter- and intrastate branching restrictions to measure a positive effect of bank competition on new incorporations; while Kerr and Nanda (2009), using a similar methodology, find both increased firm creation and churning (where new startups fail within the first years following entry).

Alternative ways to deal with the identification problem are reviewed by Shaffer (2004) through the use of tests arising from the "new empirical industrial organization" literature, such as the revenue test developed by Rosse and Panzar (1977) and the markup test of Bresnahan (1982).

Finally, Cetorelli and Strahan (2006) use the measure of dependence on external finance developed by Rajan and Zingales (1998) to determine treatment and control groups for a difference-indifferences test of whether bank competition affects the distribution of small firms' size. This is a methodology similar to the one used in my empirical test. The control group I use however, comes from a new definition of banking market that yields a measure of market power at the local level, as opposed to the state level measure provided by most of the previous literature.

\section{Banking Market Definition}

The definition of banking markets currently in $u^{3} e^{3}$ is geographical in nature. Banking markets are assumed to encompass rural areas the size of a county and urban areas the size of a metropolitan

\footnotetext{
${ }^{3}$ See United States v. Philadelphia National Bank, 374 U.S. 321 (1963)
} 
statistical area (MSA). ${ }^{4}$

Much of the existing research suggests that the relevant geographical market for lending, especially for small firms, is indeed local (see, for example, Berger, Demsetz, Scalise, and Strahan (1999)). But, for the purposes of economic analysis, this purely geographical definition is problematic because it overlooks a key fact of the commercial lending market: firms compete with one another across areas of bank influence. The dynamics of competition between borrowers across geographically defined boundaries affect firms' demand for credit and therefore, these markets

In particular, competition amongst borrowers acts as a limit to the amount of rents that financial monopolists can successfully extract. As long as a financial monopolist cannot influence its borrower's competitors, it cannot charge financing rates so high that they would price the borrower out of its own industrial market. This is true regardless of the reason a particular financial intermediary holds a position of power when negotiating loan terms with a particular borrower: few banks in the region, inside information monopoly or even legal barriers. Even a bank that enjoys an incontestable monopoly position with respect to a certain firm is affected by the level of bank competition elsewhere, as long as this firm competes with others that do not fall under the influence of the monopolist financier. The fact that the industrial markets are interconnected makes the financial markets interconnected too. Thus, I claim the relevant measure of financial competition is the number of banks "in range" of a given firm or its competitors.

I will try to clarify the issues above through the use of the following example (see Figure 1). Let us assume a world in which there are two towns (A and B). In town A there is just one monopolist bank, whereas in town $\mathrm{B}$ there are a number of banks engaged in perfect competition with one another. Banks in town B charge firms located in this town the perfectly competitive rate $\left(r^{*}\right)$, which is also the minimum rate that the monopolist bank in town A can charge its local borrowers and break even. ${ }^{5}$

\footnotetext{
${ }^{4}$ The census bureau defines an MSA as containing a core urban area of 50,000 or more population, consisting of one or more counties and including the counties containing the core urban area, as well as any adjacent counties that have a high degree of social and economic integration with the urban core (as measured by commuting time to work).

${ }^{5}$ For simplicity I will assume that firms and banks across locations are essentially identical.
} 


\section{[Place Figure 1 about here]}

The traditional analysis of bank competition implicitly assumes that all firms are like those shown in Figure 1 as belonging to industry 1. In this industry, firms located in town A do not compete with those located in town B (we can think of firms in this kind of industry as selling goods that can only be consumed in the location where they are produced, such as the services provided by restaurants or coffee shops). The limit to how much the monopolist bank can charge these firms is determined by the minimum of the rate that expropriates all surplus from them and $r_{B}$; which is the minimum rate that banks located in town B ("foreign banks") can charge firms located in A and still break even (we can think of this rate as the equivalent to "import parity" prices). This rate is in turn determined by whatever barriers $t$ sustain monopoly power in $\mathrm{A}$ (distance, information opaqueness or legal impediments to cross-border lending). The strength of these barriers to entry will determine the economic importance of a banking monopoly.

In the case of industry 1 , the difference between interest rates charged to firms in town $\mathrm{A}$ and firms in town B reflects how much market power can be exercised by the monopolist bank. Of course, if there are systematic differences between firms in town A and town B (such as firms in town A being riskier, for example) the actual difference in interest rates would be an unreliable measure of market power.

But, as I have already stated, the previous analysis misses an important feature of credit markets. In a number of cases, firms in town A will compete directly with those in town B and thus are better represented by the firms that in Figure 1 belong to industry 2 . We can think of firms in industry 2 as those that produce any real world transferable good (such as corn, crude oil, etc.). For these firms - even in the case where $r_{B}$ is high and therefore there is high potential for rent extraction by the monopolist - bank A faces another limit to how high an interest rate it can charge: the competition that its own borrowers face from firms located in town B. Because banking markets in town B are perfectly competitive, firms in B are charged the minimum possible interest rate and can themselves charge low industrial prices that reflect this. Unless there are barriers to 
competition in the industrial market (transportation costs, switching costs, etc.) or firms in town $\mathrm{B}$ are themselves industrial monopolists, firms in town A will be forced to react to the prices offered by their competitors in B and will retain little or no surplus for the monopolist bank to expropriate.

In both cases, the upper bound to equilibrium interest rates (thus how much market power the monopolist bank can exercise) is determined by the minimum of two limits to competition: (i) $r_{B}$, the limit rate that will keep "foreign" banks away (that depends on banking market structure), and (ii) the interest rate that expropriates all available surplus from the borrower. It is this second limit that varies by industry (from $r_{1 A}$ to $r_{2 A}$ ) and depends on industrial market structure. If we study firms facing demand curves that are unaffected by conditions outside the area of the local banking market (one could think of bars or restaurants as being a good example of such firms) this rate will only be limited by the monopoly rent available to the industry. ${ }^{6}$ If, on the other hand, we focus our attention on firms facing demand curves that react to prices (or industrial strategies) in markets outside the geographical span of the local banking market (any firm that sells easily tradable goods would fit this description), this rate is the interest rate that will make the borrower loose its competitive race against "foreign" firms (in effect, killing the goose that lays the golden eggs). ${ }^{7}$

In order for oligopolistic banks to successfully overcharge their local borrowers they have to overcome this second limit rate that depends on industrial market definition (which in turn depends on customers' demand curves). I therefore argue that banking market power can only be maintained (and thus should only be measured) over the industrial markets of borrowers (defined both by product choice and geographical reach).

If we look at the same difference between rates charged to industry 2 firms in town A and B, we see that the amount of market power that can be exercised by monopolist (oligopolist) financiers

\footnotetext{
${ }^{6}$ Note that even if there were many firms in city A all ferociously competing against each other, the monopolist bank could charge all firms a similarly high interest rate that forces them all to sell at the collusive price to break even and therefore expropriate all industrial surplus in the market.

${ }^{7} \mathrm{How}$ close this industrial limit rate is to the competitive interest rate depends on the level of cross elasticity of demands, industrial transportation costs and other differences in efficiency between local and "foreign" firms.
} 
is less than or equal to that which can be exercised in industry 1 (assuming conditions in both industries are similar in terms of available profit to be expropriated).

Then the difference in the differences in rates (spread) charged to firms in oligopolistic rather than competitive markets between industry A and industry B, is no longer subject to systematic differences in firms that spawn from location. The key implication of this framework for the empirical analysis of banking market power is that firms that operate across wide geographical markets should be charged loan rates closer to the competitive rate than those that operate within a single banking market, regardless of how competitive ${ }^{8}$ their local banking markets are and therefore constitute a good "control" group for testing the extent of bank pricing power

\section{Identification strategy}

The main problem with testing whether oligopolistic banks can successfully charge some borrowers higher interest rates than they would have otherwise been charged in competitive banking markets (exercise market power) is distinguishing the exercise of market power from the effect of unobservable heterogeneity in banks and/or firms that would lead to higher rates in equilibrium. For example, locations with a small supply of available funds would naturally result in a small number of banks in equilibrium and at the same time in higher funding costs, leading to high interest rates and low bank competition indices, even if the financial market was perfectly competitive. Alternatively, if firms in certain geographical areas are systematically riskier than those in other areas this could also lead to both a smaller and less profitable market for corporate loans (and therefore a smaller number of banks in equilibrium) and higher interest rates "fairly charged" to those firms.

\footnotetext{
${ }^{8}$ Even though the framework described in this section deals with a monopolistic bank, it is still applicable to situations where there is limited bank competition in one location and significant competition in others. Of course in theory, bargaining mechanisms can be designed by which just two banks can compete away all their market power; but there are also other designs that allow them to successfully collude and charge the monopolistic price. Moreover, because banks are limited by regulations in how much they can lend to a particular industry it is more plausible that a few banks can partition a loan market between them and act as this framework predicts.
} 
In order to untangle the effect of unobservable characteristics that may affect areas with few banks in equilibrium from the exercise of pricing power, I conduct a difference-in-differences test. This is done by identifying a "control" group of firms that are affected by those unobservable characteristics but are not subject to the exercise of pricing power ${ }^{9}$. We then compare how interest rates for similar firms change (for both the "treatment" and "control" groups) from areas where banking markets are competitive to those where they are not. The difference in those changes is the "true" measure of pricing power that oligopolistic banks exercise. This is a research design similar to Cetorelli and Strahan (2006), who use the measure of dependence on external finance developed by Rajan and Zingales (1998) to determine treatment and control groups for a differencein-differences test of whether bank competition affects the distribution of small firms' size.

One of the main contributions of this paper is the identification of an innovative control group of firms, very well suited for a difference-in-differences test of interest rates: those that operate on industrial markets that span wide geographical areas, encompassing several banking markets.

This "control" group offers several advantages. The first is that whether a firm belongs to it or not depends on customers' preferences and therefore can be safely considered to be exogenous to equilibrium conditions in the banking market, ${ }^{10}$ in much the same way that a firm's choice of industry is considered exogenous.

The second advantage is that it provides a conservative estimate of the level of pricing power (if any) exercised in less competitive banking markets, robust to most mismeasurement errors derived from a strict binary classification.

It is clear that in the real world there are many degrees of overlap between financial and industrial markets and that firms whose industrial marketplace only barely exceeds the reach of

\footnotetext{
${ }^{9}$ Or, at least, subject to smaller price distortions due to lack of competition in the banking markets

${ }^{10}$ One could worry that tight conditions in credit markets leading to a small number of banks in equilibrium might affect funding and firm creation and therefore make both variables endogenous, but SSBF data does not support this hypothesis: Table I shows that the number of firms in the population for both competitive banking markets and those that are not is statistically identical. Furthermore, even if this were the case there is no apparent reason why this mechanism should affect only firms that compete within a single banking market and thus would not threaten our no omitted interactions assumption.
} 
their banking markets can still face substantial pricing power. However, by classifying all those firms whose competitive footprint exceeds the geographical definition of banking markets as part of the "treatment" group we are only biasing the test results against finding any exercise of market power.

Also, as long as industrial prices in less competitive banking markets do not exactly match related industrial prices in "foreign" (and competitive) banking markets $(\lambda>0$ in Figure 1), there is some scope for firms whose industrial markets are defined across wide geographical areas (the "control" group) to be overcharged by local oligopolistic banks too. If this is the case, the measured difference between firms whose markets are confined to a single banking market and those that span several banking geographies would again be a lower bound on the level of pricing power being exercised.

Another posible problem with the test is the case in which $\lambda$ (the determinant of the level of industrial competition barriers to entry) is related to barriers to entry in the banking market. In this case, the maximum overpricing that monopolist banks can exercise is the same as above, but it would be impossible to disentangle whether the measure quantity is because of barriers to entry in the banking market, or because of lambda. In this case my treatment and control groups would be identical and that would bias my test towards finding no effect.

I use this new definition of banking markets to perform a difference-in-differences test with data from the SSBF that allows me to classify all firms in the survey according to relatively good proxies for the level of bank and industrial competition for a given geographical footprint. In this case, whether or not they compete primarily in their local markets. With this information I can subdivide the SSBF respondents into four subpopulations by cross tabulating the variables measuring banking competition and geographical extension of industrial competition. I then test for systematic differences in loan rates between these four subpopulations that cannot be attributed to the traditional determinants of loan pricing.

The characterization of banking markets as having a local geographical span is the most com- 
monly used in the banking literature (see, for example, Hannan (1991)), and has seen empirical support based on surveys of customer behavior (see Gilbert (1984) for a general overview), data for commercial loans ${ }^{11}$ and even bankers' own views ${ }^{12}$.

The commonly available measure of banking competition is the Herfindahl index of commercial bank deposit concentration for the MSA or county where a firm's headquarters are located, derived from the FDIC Summary of Deposits data. The Herfindahl index is calculated as the sum of the squared market shares of all market participants multiplied by 10,000. The SSBF only reports this data categorically: whether this index is less than 1,000; between 1,000 and 1,800; or greater than $1,800 .{ }^{13}$ It is this last category that I will consider corresponding to non-competitive banking locations, whereas I will consider competitive locations those falling under the first two categories.

Once equipped with a measure of geographical bank competition, ideally I would like to measure both the strength and the geographical reach of the industrial competition faced by firms located within that area. The SSBF allows us to directly measure the geographical footprint of a company's business, giving us a very accurate proxy for the geographical area over which its market is defined. In the survey, firms were asked "Where does the business primarily sell or deliver its products or services?" This question was coded D3 in the SSBF questionnaire and allowed a total of nine possible answers in increasing order of geographical span, of which the first two ("within the city of the firm's main office" and "within the county/Metropolitan area of the firm's main office") refer to the same MSA (or county) over which the degree of banking competition is calculated. It is therefore possible to separate firms that "primarily conduct business" in the same geographical area over which banking markets are defined from all other firms, ensuring that there is an accurate

\footnotetext{
${ }^{11}$ The Survey on Small Business Finances (SSBF) shows that, in 2003, $75 \%$ of all loans to small firms where arranged by banks located less than 12 miles away from the firm's main office, and $90 \%$ of loans where arranged by banks located less than 32 miles away.

12 Guiso, Sapienza and Zingales (2004) report that "the president of the Italian Association of Bankers (ABI) declared in a conference that the banker's rule of thumb is to never lend to a client located more than three miles from his office."

${ }^{13}$ For illustration purposes, a market evenly split between five banks would score a Herfindahl Index of 2,000 , whereas one evenly split between six banks would score a Herfindahl Index of 1,667 and one evenly split between ten banks would score 1,000 .
} 
criteria for inclusion of observations into the "treatment" group.

By classifying a firm as part of the "treatment" group I assume its competitors all fall within the area of influence of the same geographically defined banking market. Thus, I am implicitly assuming that firms' actual geographical reach matches their potential (determined by the demand curves they face) reach. It is potential demand what determines whether firms should be considered part of the "control" group or not, as discussed above.

It could however, be the case that a firm chooses to sell its goods only locally even if its potential market has a wider geographical footprint. ${ }^{14}$ This potential misclassification problem can only lead to a downward bias in my estimates, as I would expect such a firm to be charged high interest rates, when by virtue of having broad geographical markets it is not likely to be overcharged.

\section{Empirical test}

\section{A. Data}

The 2003 Survey of Small Business Finances (SSBF) was conducted for the Board of Governors of the Federal Reserve System in order to provide information about a representative sample of small businesses in the United States. The survey was first conducted in 1987 and repeated in 1993, 1998, and 2003. ${ }^{15}$

The data set is well known in the literature. Petersen and Rajan (1994) were the first to use data from the 1987 survey in order to study how banking relationships expand credit availability for small firms. Since then, the SSBF has been used on numerous occasions to study the interrelation between banking market structure and small business finances (see, for example, Craig and Hardee (2007) or Cole, Wolken, and Woodburn (1996)).

According to the survey's codebook, the target population for the survey is "all for-profit, non-

\footnotetext{
${ }^{14}$ The opposite case of misclassification is not feasible as a firm's market cannot, by definition, be smaller than its sales area.

${ }^{15}$ Complete documentation on the SSBF, including codebooks and detailed questionnaires, can be found at http: //www.federalreserve.gov/Pubs/Oss/0ss3/nssbftoc.htm
} 
financial, non-farm, non-subsidiary business enterprises that had fewer than 500 employees and were in operation as of year-end 2003 and on the date of the interview" (from June to December 2004), representing a total population of 6.3 million small businesses. The 2003 SSBF data that I use in my analysis consists of a sample of 4,240 small businesses. Of these firms: 1,897 (44.7\%) applied for a loan at some point during the three previous years; 1,757 (41.4\%) were (eventually) approved; and 1,607 (37.9\%) obtained a loan from an arm's length institution (as opposed to a captive financial institution that was part of the borrower's group). This final group will constitute the population of interest for most of the empirical analysis in this paper. Loan terms in the database are those of the most recently approved loans (MRAs), including lines of credit (1,053 observations, or $66 \%$ of the population of interest), capital leases (17 observations, or $1 \%$ of the population), mortgages (153, or $10 \%$ of the population) and other loans (381 observations, or $24 \%$ of the population).

The survey was designed as a stratified random sample, with over-sampling of the (relatively) larger firms (those with 20 to 499 employees). The 72 strata in the sample were generated by the cross classification of three variables: number of employees, urban/rural status and census division of firm's location, to ensure adequate representation of all subgroups.

Cross classifying the dummy variables measuring bank competition and geographical extension of industrial competition I end up with a total of four subpopulations. Table I shows the number of observations for each subpopulation, as well as the estimate of what percentage of the total survey target population each subpopulation represents. Note that the size of each of the four subpopulations is similar, both if we include all firms regardless of whether they asked for or obtained finance, or if we focus exclusively on those businesses with an approved loan in the previous three years.

\section{[Place Table I about here]}

The next step in the analysis is to describe the key characteristics of the firms in each of the subpopulations and try to ascertain whether there are significant systematic differences between 
them that could account for the difference in spreads without recourse to the difference in market structures. In panel A of Table II I tabulate the average levels of the main variables describing firm characteristics for all firms and for those with approved bank loans for each of the four subpopulations: (i) firms that compete within a single banking market, where banking competition is limited; (ii) firms that compete within a single competitive banking market; (iii) firms that conduct their business on a larger geographical scale than the county, where their local banking markets are non-competitive; and (iv) firms that compete in wider-than-local markets, where local banking markets are competitive.

\section{[Place Table II about here]}

Most of the objective firm characteristics are quite similar between subpopulations, both if we look at the entire spectrum of firms or just focus our attention on those with recently approved loans. Although there appear to be significant differences in firm size and leverage between the subpopulations based on whether firms compete locally or not (firms that compete within single banking markets are significantly smaller and less levered than those that compete in regional or national markets), these differences affect locations where banking markets are less competitive in the same way as those were banking markets are more competitive and persist whether or not firms get bank loans.

Panels B and C of Table II underscore the fact that, apart from a significant difference in interest rates between firms whose markets all lie within areas where banking competition is limited, most loan characteristics are also similar across subpopulations; as are measures of the difficulty with which firms in all subpopulations can access finance. There are however, significant differences that only apply to firms that compete in wide markets and are located in places with competitive banking markets. These firms are more often rejected credit, and when they do get credit it is shorter term, more likely to be secured and at a variable rate. 


\section{B. Regression specification}

In order to analyze the determinants of interest rates charged to small firms I use a differencein-differences specification. ${ }^{16}$ Taking advantage of economic theory, I select a group of observations (loans pertaining to firms that compete across wide geographical markets - the "control" group) that should not be affected by changes in my variable of interest (the level of banking market power). This allows me to control for potential unobservable differences between those observations that were and were not "treated". The general specification is:

$$
\begin{aligned}
y_{j} & =\alpha_{1} \text { LowCompetition }_{j}+\alpha_{2} \text { SmallMarket }_{j} \\
& +\beta \text { LowCompetition }_{j} * \text { SmallMarket }_{j}+\mathbf{Z}_{j} \delta+\epsilon_{j}
\end{aligned}
$$

Where, $j$ is an index across observed loans; SmallMarket $_{j}=1$ if the borrower competes within only one geographically defined banking market (thus belonging to the "treatment" group) and SmallMarket $_{j}=0$ if it competes in wider geographical markets (and is therefore part of the "control" group). LowCompetition $j$ is an indicator of bank competition, equal to 0 if the lender is in an area where banking markets are competitive and equal to 1 if not. The dependent variable, $y_{j}$, is the spread of the interest rate charged for the latest approved loan that firm $j$ had (if any) in the past three years over the prevailing prime rate ${ }^{17}$ in the same month and year when the loan was approved, as reported by the Federal Reserve on its H15 Report. This spread measures both the prevailing cost of capital for investments with a risk profile comparable to that of a bank's better clients, and an estimate of the average operating costs of banks. Finally, all additional explanatory variables are captured by the vector $\mathbf{Z}_{j}$.

Several potential threats to the internal validity of the analysis (such as the effect of omitted

\footnotetext{
${ }^{16}$ For a detailed exposition of the method see, for example, Meyer (1995).

${ }^{17}$ Other related papers (see, for example, Rice and Strahan (2010)) use the interest rate as the dependent variable and the prime rate as one of the regressors. The results reported remain essentially the same if we were to adopt that specification, but I believe that the one chosen here makes interpretation of the main and interaction effects as drivers of the rate spread clearer.
} 
variables, mismeasurement or trends in outcomes) are greatly reduced through this approach, as $\alpha_{1}$ summarizes the way in which both groups ("treatment" and "control") are influenced by lack of bank competition and $\alpha_{2}$ takes care of any systematic differences between both groups that are independent of whether firms are in a competitive banking market or not; leaving $\beta$ as the true causal effect of the "treatment" on the outcome.

In general, the key identifying condition in this setup is that the only interaction relevant for the independent variable is the treatment under study (no omitted interactions). In the terminology of my setting, the assumption is that the only interaction between LowCompetition $=1$ and SmallMarket $=1$ relevant for loan pricing is the exercise of market power by oligopolistic banks. I assume that, after accounting for the usual determinants of interest rates (control variables), systematic differences between "treatment" and "control" groups (if any) are similar in competitive and non-competitive banking markets. In other words, that in absence of "treatment" observations where SmallMarket $=0$ and those where SmallMarket $=1$ would have followed parallel paths.

However, this main identifying assumption cannot be itself tested and, if not true, there are alternative explanations for the test results. In Section V.B , I present these alternative explanations and discuss the evidence that supports my interpretation of the data.

\section{B.1. Control variables}

In order to measure the effect that the lack of bank competition elicits in equilibrium interest rates, I need a good benchmark for what loan rates would have been under competitive markets in both the industrial and financial sectors. Following Petersen and Rajan (1995), Hale and Santos (2009) and Rice and Strahan (2010), I include a number of control variables in the specification of the empirical tests to account for all previously identified factors that might determine interest rates in equilibrium: borrower controls, macroeconomic environment variables, variables describing the operation of the credit markets, and those describing relationship and loan characteristics. 
Firm level controls. To control for the effect of differences in borrower characteristics that might impact riskiness or available industrial surplus, I include as regressors several measures of firm profitability, such as the firm's operating margin (EBIT/sales), return on assets (net income/ assets), and turnover ratio (sales/assets). I also include the ratio of the firm's operating margin to the average operating margin of other firms in the same two-digit SIC code, as a way to measure the level of equilibrium surplus (and therefore industrial market power) that the firm enjoys. Furthermore, I adjust for the fixed effects of the firm's industry by including dummy variables for its SIC code. Regrettably for my purposes, the former measures may represent estimates of either a firm's riskiness, its efficiency, or its market power depending upon the assumptions one makes about the precise nature of firm competition and are therefore not clear controls for idiosyncratic risk. My dataset only provides two variables that can reliably be considered to measure only riskiness: (1) leverage ratio (total debt/assets), and (2) a direct measure of the credit rating of the borrower derived from the Dun and Bradstreet credit score of the company - a number varying from 1 (safest) to 5 (riskiest). I include both of them as controls in my specification.

A very important firm level characteristic is size. It may account for pure bargaining power, riskiness, investment opportunities, or information opacity: all of which are important factors underlying the dynamics of interest rates. In my test specification, I measure firm size through the logarithm of the book value of assets and the number of employees. I also consider the possibility that growing firms are subject to different pricing regimes than those under decline and add an indicator showing if sales have increased in the past year.

The last set of firm specific controls deals with the borrower's age. Following Petersen and Rajan (1995) I consider that oligopolistic banks may react differently from those in competitive markets to the uncertainty surrounding young firms. In order not to let this possibility interfere with the test, I control for the effect the logarithm of firm age has on the interest rate spread independently for firms in competitive banking markets and those in non-competitive ones. 
Macroeconomic and application process controls. The dependent variable in my regression, the interest rate spread over the prevailing premium rate at the time, adjusts for both average funding costs and an estimate of average bank operating costs. To isolate any remaining effects of capital market-wide conditions, I control for the term structure of interest rates (calculated as the spread of the ten year Treasury Bond over the three month T-Bill) and the credit rating spread (calculated as the difference between the average interest rate on a BBB bond over an AAA bond).

I also look at the application process itself, measuring the number of times the borrower applied for a loan, the number of loan renewals, an indicator of whether the borrower was ever denied a loan in the past three years, and another indicator of whether it did not apply for a loan for fear of refusal. All these variables can point to, otherwise unobservable, borrower quality concerns as well as self-selection issues. Because distinct corporate governance structures may signal (or result from) agency problems, I control for their possible effect on equilibrium interest rates through indicators that measure if the firm is a corporation (including S-corporations), owner-managed, or family owned. I control for the effects of geographical location by including 9 geographical dummies and an indicator for whether the headquarters of banks and firms lie in rural or urban areas.

Relationship and lender controls. Because the characteristics of the lender can determine different pricing systems I include indicator variables for whether the financier is a bank, a nonbank financial institution (such as an insurance or a leasing company), or other (individual, venture capitalist, etc.).

There is a large body of literature analyzing the positive effects that relationships between borrower and financier can have on loan characteristics (see Boot (2000) for an excellent review). A financier, for example, can acquire proprietary and reusable information by repeatedly lending to the same firm, helping to alleviate adverse selection and agency problems and reducing equilibrium interest rates. In an effort to measure the strength of each player's bargaining position, I include in my model the length of the relationship between lender and borrower (in years) and whether the lender is considered by the borrower to be its "primary" financier. But intensity is not the only 
relevant measure of relationship for loan pricing. Degryse and Van Cayseele (2000) find that broader relationships in which the financier has access to other informative services with the borrower (cash management, credit card processing, etc.) reduce asymmetries of information and are reflected in lower rates. To measure the breadth of relationships, I include three indicator variables in my model that measure whether the firm has deposits, information, and/or non-information services with the institution that approved the loan.

There is however, a cost associated with relationship banking: the potential hold-up problem stemming from the relationship bank's information monopoly (see Rajan (1992)). Multiple relationships can alleviate this potential hold-up problem. To control for this effect, I look at all relationships that the borrower has with other financiers: I measure the total number of relationships that the borrower has with financial institutions and the number of lending relationships. In order to put these into context, I also control for the longest lasting relationship the borrower currently has, and the distance to the furthest removed financier with which the borrower has a relationship (that indicates the potential area over which the borrower has some bargaining power).

Loan level controls. Several theoretical papers (see, for example, Sengupta (2007) and references therein) have pointed out that by adjusting the contractual structure of loans (amount, maturity, security, etc.) firms can change their inherent risk profiles and also signal their quality to potential financiers and thus influence their equilibrium interest rates. I include a number of regressors in the model that account for the more salient loan characteristics likely to result in different pricing regimes. There are dummy variables that indicate the type of loan (line of credit, capital lease, mortgage, vehicle loan, equipment loan, or other), whether or not there was any kind of security attached to the loan (collateral, compensating balance, or personal guarantee), whether the agreed upon interest rate was fixed or variable, whether the loan was a renewal or a de novo loan, and 6 dummy variables indicating the presence of each type of tabulated collateral (inventory or accounts receivable, business equipment or vehicles, business securities, business real estate, personal or other assets). 
Failing to control for these characteristics could interfere with my empirical test if they have a significant impact on pricing and are not evenly distributed amongst subpopulations. On the other hand, if we include as explanatory variables loan characteristics that are likely to be determined simultaneously with interest rates we could significantly bias our estimates. In the base specification of my model I have therefore only included a few key loan characteristics that may determine different pricing regimes but can be reasonably construed as exogenous. Nevertheless, the results presented in Table III (where I estimate a model with no loan characteristics as regressors and obtain essentially the same results) show that no appreciable bias is incurred in.

\section{C. $\quad$ Test results}

The population of interest on which the regression is estimated is comprised of those companies that have some kind of loan (including lines of credit) approved in the three years ending December 2003 (1,757 or $41.4 \%$ of observations). Firms with loans from captive financiers are dropped from the sample ( 86 or $2 \%$ of observations) as are those whose area of competition does not fit into the theoretical framework ${ }^{18}$ (42 or $1 \%$ of observations).

I estimate the regression above using weighted least squares, taking the sampling weights provided by the SSBF that account for oversampling of larger firms and unit non-response. Since there may be a common element to the regression error across firms in each of the four subgroups I cluster standard errors by subgroup.

\section{[Place Table III about here]}

The first column of Table III reports my benchmark regression, linking the interest rate spread paid on the most recent loan to the level of bank competition. The key metric I am concerned with is the coefficient on the interaction between the indicator variable for lack of bank competition and the one for geographical span of industrial competition. As predicted by my main hypothesis, this

\footnotetext{
${ }^{18}$ Firms that primarily sell their goods outside USA (32), over the internet (4) and those that answered "other" (6) to question D3.
} 
coefficient is statistically significant at the $5 \%$ level and economically important. This leads me to conclude that indeed small firms whose markets all lie within areas where banking competition is limited are being "overcharged" relative to fully competitive "fairly priced" loans. The interaction effect is economically significant, entering the specification at 69 basis points, and thus accounting for a third of the average spread (211 basis points, with a standard deviation of 14 basis points), or $10 \%$ of the average interest rate in the sample $(6.56 \%)$.

If we center our attention on the main effect of the LowCompetition variable, we see that its size is large (around 150 basis points) but not statistically significant. In comparison, the effect of competing only within a single banking market is negative, somehow significant (at the $10 \%$ level) and of a smaller magnitude (30 basis points). Neither of these results are very strong basis for any significant inference, but the sign of the main coefficient on the SmallMarket variable points to the fact that uncertainty about demand and competition (easier to dispel if borrowers operate exclusively within a single banking market) may have a larger impact on pricing than increased risk due to concentration of sales in a local market.

As expected, there appear to be a number of different pricing regimes: dummy variables for whether the rate was fixed or variable, whether the loan was a renewal or not, and whether there was any security involved are all significant and economically important (entering the specification at between 60 and 150 basis points). Other critically important variables are those related to the nature of the financier: loans issued by non-banks are significantly more expensive (283 basis points) than those issued by banks (the difference being statistically significant at the $5 \%$ level).

What may be the more puzzling result shown in Table III is that, with the exception of asset size, the term structure premium and sales growth, very few other variables appear to have a statistically significant impact on the interest rate spread. ${ }^{19}$ In particular, in terms of relationship

\footnotetext{
19 Rice and Strahan (2010) also find no significant effect of most of their control variables, in particular, relationship variables. This is consistent with the fact that previous literature has often found contradictory results when estimating the effects of relationships on interest rates. For example, Berger and Udell (1995) find small firms with long banking relationships pay lower interest rates on their lines of credit, whereas Petersen and Rajan (1994) cannot find a statistically significant effect of relationship length on interest rates.
} 
variables, only primary status seems to have a significant impact on prices. Loans obtained from the self-described primary bank are 43 basis points more expensive than those obtained from other institutions (again statistically significant at the $5 \%$ level).

To demonstrate the robustness of my results, I estimate several variations of the baseline model (Model I, in Table III). Specifically, I fit a more parsimonious specification (Model II) without any loan variables as regressors to prevent any simultaneous equation biases. I also estimate a series of models based on the specifications of the most influential papers in the literature that analyze the effect of bank competition on interest rates using SSBF data. Model III follows the specification of Rice and Strahan (2010) as closely as possible with the public data available. Model IV follows the specification of Petersen and Rajan (1994), while Model V follows Petersen and Rajan (1995). Compared to Model I, these models include fewer variables measuring firm characteristics, the relationship between lender and borrower and important loan characteristics such as whether the loan is a renewal. The key difference between Model IV and V is that the latter allows for firm age to influence interest rates differently depending upon the level of bank competition. Table III shows that the sign and magnitude of the coefficients of interest does not change substantially across model specifications.

\section{Robustness and alternative explanations}

\section{A. Robustness}

The main threat to the validity of the difference-in-differences design I use is the possibility of an interaction between SmallMarket $=1$ and LowCompetition $=1$ other than the one under study (omitted interactions). If this were the case, there would have to be a factor specific to firms whose markets all lie within areas where banking competition is limited (and only to them) that would result in higher equilibrium interest rates.

Because our problem does not allow us to assign observations randomly to the "treatment" 
and "control" groups, I will have to test whether any systematic difference between both groups is similar in competitive banking markets and those that are not. In other words whether, had banks not exercised market power, observations for firms that compete in wider geographical markets and those that do not would have followed parallel paths.

The "treatment" and "control" groups are similar along some very important characteristics, such as firm age and risk profile. If we look at Table II, we see that credit score ratings are essentially the same across subpopulations (both amongst all firms and those that received financing), whereas the fact that firm age and growth trends are also indistinguishable across subpopulations (see Table II, Panel A) should allay fears about systematic differences in investment opportunities.

Another encouraging fact is that the sample is well balanced. The number of observations in each of the subgroups (treatment and control for both competitive and oligopolistic banking markets) is statistically identical (see Table I). This is not a result of the sampling process, as the variables that determine the subgroups (geographical area of operation and level of bank competition) are not related to those used to determine sampling (number of employees and location in either urban or rural county, as well as within a particular census division). Furthermore, the fact that the panel remains well balanced when only those in the subpopulation of interest are considered means that it is unlikely a self-selection process be driving the results.

However, not all observable characteristics are similar across subgroups. Although all of these characteristics are controlled for parametrically in the various specifications of the main regression, it could be the case that non-linearities in the data-generating process, differing pricing systems or interactions between drivers may account for the empirical results if relevant variables change significantly between "treatment" and "control" groups. To ascertain whether this constitutes a problem for the robustness of my results, I perform non-parametric tests on the effect those variables that vary between groups may have on equilibrium credit spreads. 


\section{A.1. Dissimilar Firm Characteristics}

Table II panel A shows that an overwhelming majority of observations in rural areas are also in oligopolistic banking markets. Although I control for urban/rural status in all specifications of the test, one might worry that the parametric control is not enough. In order to address this concern, the second column in Table IV shows that the results of fitting the baseline model to a restricted sample consisting exclusively of observations in urban locations continue to support the hypothesis of banks "overcharging" firms whose markets all lie within single banking markets. As the coefficient of the interaction term enters the specification at almost twice the level of the unrestricted sample (123 basis points) and is statistically significant at the $1 \%$ level.

\section{[Place Table IV about here]}

Next, I analyze the most important variable where the four subpopulations of interest in my study are indeed significantly different: firm size (see Table II). This is a critical variable in the corporate finance literature as it can proxy for a number of key structural parameters, such as information opacity, bargaining power, or probability of success. In order to test whether it is variation in firm size that drives my empirical results, I control non-parametrically for firm assets. The third and fourth columns on Table IV show how the coefficients for the main and interaction variables still exhibit the same pattern when I break the population into two groups based on median assets and estimate two separate regressions, in effect interacting this categorical version of size with all other variables in my specification. The economic and statistical significance of the effect persists on both subsamples, with the smaller firms being subject to larger distortions from lack of bank competition: a coefficient on the interaction term of 95 basis points, as opposed to 62 for larger firms and 69 for the entire sample.

Another area where there are systematic differences between firms that operate across wider geographical areas and those that do not is the type of business they conduct. These differences, however are stable between areas where banking markets are competitive and those where they are 
not and therefore do not break the "parallel path" condition. A look at Table V shows us that "heavy" industries such as mining, manufacturing, transportation, utilities, and wholesale trading are more prevalent amongst firms that operate across wide regions, whereas retail trade is more prevalent amongst firms that compete within a single banking market and services and construction are roughly equally distributed.

\section{[Place Table V about here]}

In order to ensure this variation in industry type is not driving my empirical results, I perform another non-parametric test. Table VI shows how the coefficients for the main and interaction variables still exhibit the same pattern when I break the population into two groups based on industry type and estimate a separate regression for each group. The second column of the table shows the results for heavy industries, while the third column contains all other main buisness categories.

\section{[Place Table VI about here]}

\section{A.2. Dissimilar Loan Characteristics}

It can be argued that different loan types follow different pricing systems and thus the fact that lines of credit are significantly less prevalent amongst firms that operate within a single banking market (representing $49 \%$ of the loan population for firms whose markets all lie within areas where banking competition is limited, and $61 \%$ for those in competitive banking markets) than amongst firms that compete over wider areas (see Panel C of Table II) - even if the differences appear to follow parallel paths - could be clouding the empirical results. The first three columns of Table VII summarize the results of a non-parametrical test of this alternative hypothesis. Columns 2 and 3 show the coefficients for the main and interaction terms when the model is fitted independently for lines of credit and all other loan types. Even though the effects of limited bank competition on firms 
that compete within a single banking market are almost four times bigger for term loans than for lines of credit (120 basis points versus 29), in both subgroups the coefficient on the interaction term is positive and statistically significant at the $5 \%$ level. This result confirms that even if different pricing systems are in effect they do not detract from the key empirical insights.

\section{[Place Table VII about here]}

Finally, in columns four and five of Table VII, I perform the same analysis for long term (those with maturities longer than 12 months) and short term loans. Panel C of Table II shows that only $49 \%$ of loans for firms that operate across wide areas located in competitive banking markets are long term, whereas in all other subgroups this figure lies between $59 \%$ and $62 \%$. This systematic difference between subgroups could be cause for concern. However, the non-parametrical test reported in the last two columns of Table VII shows that both coefficients remain positive and significant (at the $5 \%$ level for short term loans and slightly above it for long term loans). Although the coefficients on the interaction term suggest that short term loans are more profoundly affected by the exercise of market power (127 basis points as opposed to only 46 for long term loans).

\section{B. Alternative explanations}

I interpret the empirical results of the previous sections - that interest rates for firms that operate mostly within the geographical area of banking markets where competition is limited are systematically higher that those of their peers - as providing evidence that the concentration of market shares in banking leads to the exercise of significant market power in the pricing of loans to firms whose geographical footprint coincides with that of the oligopolistic banks. However, the main identifying assumption of the empirical analysis cannot be itself tested and, if not true, there are alternative explanations for my empirical results. Below I present these alternative explanations, along with the reasons why they are less likely to account for the observed results.

There are two main kinds of alternative hypotheses: those that posit that there is no (significant) exercise of market power (the commercial loan market for small firms is competitive) and those 
that posit that indeed market power is being exercised by oligopolistic banks, but that some kind of friction (and not industrial market structure) explains the higher interest rates that firms whose markets all lie within areas where banking competition is limited face.

\section{B.1. First Alternative Hypothesis}

If we adopt the position that the credit market for small firms is reasonably competitive (the first alternative hypothesis), then no monopoly power is being exercised by banks and the variability in interest rates charged corresponds to observable and unobservable differences in the equilibrium determinants of competitive interest rates: (i) bank costs, (ii) price and availability of alternative sources of funding (credit demand), and (iii) firm risk profile. I will examine each of these possibilities in turn.

For any of these three alternatives to successfully explain my empirical results, they should meet all of the following criteria: First, they would need to not have been controlled for by all other sources of risk and relationship in the model's specification; second, they would need to justify higher rates for firms that compete exclusively within a single banking market and not for those that compete across broader geographical markets; finally, they would need to affect only those firms that operate in locations where the banking sector is least competitive.

Differences in bank costs. Bank cost structure could be related to both lack of bank competition and higher interest rates. Small markets (or those with low saving rates) naturally support few banks and could mean high funding costs or operating costs (if fixed establishment costs have to be spread over low loan volumes). This may lead to higher interest rates without recourse to the exercise of market power. However, this hypothesis does not explain differences between firms that operate only locally and those that compete over wider areas as none of the higher costs are specific to any firm type. Costs that could be directly associated to a particular firm (information gathering, for example) are likely to be lower for firms that compete within the local banking market than for those whose competitors span a wider area, suggesting that, if anything, heterogeneity 
in banking costs should lead to lower interest rates for local firms, not higher. ${ }^{20}$

Differences in credit demand. Another alternative explanation for my results could be an increase in credit demand due to a shift away from alternative funding sources. Firms in our population of interest have minimal access to organized markets for either debt or equity. ${ }^{21}$ Therefore the choice they face is between monitored bank debt, internally generated funds, and private equity (be it from insiders, family and friends, or institutional investors). SSBF data allows us to answer this concern directly, as firms are asked about their demand for debt and equity financing. The survey contains data on whether companies applied for any loan in the past three years or even if they did not apply through fear of denial but would have wanted to. Panel B of Table II shows that there is no statistically significant difference in the percentage of firms that demanded debt or any kind of financing across subpopulations.

Differences in firms' risk profiles. The last alternative explanation for my test results that claims banking markets are competitive is that firms whose markets all lie within areas where banking competition is limited are somehow riskier than their peers and therefore their higher interest rates are justified. In order to ascertain the relative merit of this explanation we need to further analyze the characteristics that this unique risk factor(s) should have.

In order for this unobservable risk source to affect only firms that operate within a single banking market, it should come from the revenue side of the firm's business (as cost factors are likely to affect all firms irrespective of where they sell their products or how mobile their customers are). In this case, we would expect some of this systematic difference in risk between subpopulations to be reflected in objective risk measures that the model controls for, like the Dun and Bradstreet credit score. And yet, as Table VIII shows, the distribution of risk categories between subpopulations does

\footnotetext{
${ }^{20}$ This interpretation is supported by the finding of a negative coefficient for the main effect of the SmallMarket variable in the full regression.

${ }^{21}$ Although I have no data on bond issuance, out of the 4,231 firms in our sample, only 9 were traded in organized equity markets and due to their size it is reasonable to assume organized bond markets are also closed to them, specially to those that compete only at the local level.
} 
not support the hypothesis that firms whose markets all lie within areas where banking competition is limited, are riskier, neither on average, nor notch by notch. If anything, it appears that they are less risky than their homologues located in competitive banking markets, as they show a statistically significant higher proportion of top rated firms. This is true both in the entire population of firms and in those that are bank financed.

\section{[Place Table VIII about here]}

Yet, the risk factor that makes firms that operate within a single banking market riskier may just be the fact that they have such a concentrated market. The argument goes like this: banks that lend to local firms bear more risk because their portfolio is not diversified with respect to local economic shocks, therefore they should charge higher interest rates. There are two problems with this argument. First, if this was the main driver of higher interest rates it would apply to regions with competitive and oligopolistic banking markets. But it does not, in fact firms that sell their products within a single banking market are charged systematically lower rates than those with a wider geographical footprint (see the coefficients for the SmallMarket main effect on Table III). Second, loans originated by bank holding companies (those with many branches) and therefore likely to be able to diversify away whatever unobservable local risk factor might have been driving interest rates up, still exhibit the same results as reported above. Columns 2 and 3 of Table IX show that the coefficient of the interaction term when the model is fitted independently for loans with banks that belong to bank holding companies and those that do not remains positive and statistically significant at the $5 \%$ level (or better) for both populations. The effect on loans with banks that do not belong to bank holding companies is much larger than the one reported in Section IV (333 basis points as opposed to 69), showing that indeed they consider local loans riskier, but even for bank holding companies the effect of bank market power on interest rates is significant (39 basis points).

[Place Table IX about here] 


\section{B.2. Second Alternative Hypothesis}

The second competing hypothesis essentially posits that the binding constraint on the interest rate that oligopolistic banks can charge its borrowers is not determined by the level of industrial competition, but by the limit pricing that forestalls competition from other banks $\left(r_{B}\right.$ in Figure 1). If financial barriers to entry are systematically higher for firms in industries with broad geographical markets than for those that operate within a single banking market, ${ }^{22}$ then both my hypothesis and this alternative explanation would yield the same empirical predictions and would be almost indistinguishable. The main difference is that the alternative hypothesis provides no explanation for why there is any surplus at all to be expropriated in the first place. In order to find an economically significant rent being extracted by oligopolistic banks, proponents of this explanation have to make ad hoc assumptions about the level of industrial competition in the United States; whereas my explanation of the empirical results provides a reason both for the existence of industrial surplus and the banks' ability to extract it.

However, there are other potential sources of variation in financial barriers to entry that are not systematically driven by the geographical span of industrial markets and that could still provide an explanation of my empirical results.

The first candidate could be differential access to finance. The assumption here is that firms that operate within a single banking market have a more difficult time reaching out to outside banks and are therefore in a worse bargaining position with respect to their local lenders. Although it is apparent from the geographical definition of banking markets that distance from headquarters to bank may play a role in financing (either because of search arguments or monitoring costs), it is much less clear that this should only apply to firms that operate within a single banking market. In order for access to finance to correlate with the geographical span of sales one would have to argue that credit is sought through the same channels (the same agents) that deliver goods or services. Also, this argument assumes that banks do not solicit business across geographical areas.

\footnotetext{
${ }^{22}$ This could be the case, for instance, if the main barrier to lending across distances was knowledge of a firm's customers and/or competitors.
} 
A much more likely candidate barrier to entry is asymmetry of information. Boot and Thakor (2000) and Sengupta (2007) consider potential new entrants face significant barriers to entry caused by the winner's curse problem they encounter when trying to sort out bad credits from those being overcharged by incumbent monopolists. And even though the incumbent's informational advantage likely applies to all firms in matters of costs and character, if a firm's demand is exclusively located in a single banking market the cost for potential competitors from any other banking market of becoming informed are so much higher. To show that product market competition, and not availability of information, is limiting the exercise of monopoly power by banks, I need to find a group of observations with high informational opacity that are nevertheless not being systematically overcharged by oligopolistic banks due to high industrial competition. Column 2 of Table IX shows what happens when we restrict our attention to the young firms in the sample (those at or below the median firm age of 16 years). We would expect these firms to suffer from large information opacity, and yet the interaction coefficient is still positive and significant (121 basis points compared to 69 for the full sample) whereas the main coefficient for LowCompetition is not significant. This would lead us to conclude that, even in this case of information opacity, firms that operate across wide geographical areas are not being overcharged by their local oligopolistic banks. This effect persists if we look at more extreme cases of information opacity due to firm age. Column 3 of Table IX shows that firms with 9 or less than 9 years of age $\left(25^{\text {th }}\right.$ percentile $)$ exhibit similar, if less statistically significant, results due to a smaller sample size.

\section{Conclusion}

In this paper, I analyze the consequences of integrating the insights of the vertical integration paradigm of industrial organization into the study of bank competition. Once we recognize banking as upstream to any product market, we realize that even if oligopolistic banks are able to establish barriers that insulate them from competition from outsiders (or from the threat of new entrants), they might still not be able to overcharge their small firm borrowers. The reason is that banks in 
other areas might be able to lend to a firm's competitors at lower rates, thus conferring these firms a strategic advantage in the industrial market and effectively limiting the available surplus that the oligopolistic banks can extract. Therefore, the maximum amount of overcharging that can be successfully exercised by oligopolistic banks is limited by the minimum of the market structures in the financial and the industrial markets. Accordingly, I propose to measure the degree of competition in the commercial banking market not by the number of banks that are "in range" of a given firm, but by the number of banks that are "in range" of a given firm or its competitors.

Using data on firm, loan, and bank characteristics from the Survey of Small Business Finances I perform a difference-in-differences test to isolate the effects of bank competition on interest rates charged to small firms. This test shows that firms whose competitive footprint falls entirely under the area of influence of an oligopolistic banking market are systematically charged higher interest rates than their peers. An overpricing that cannot be explained the usual determinants of lending dynamics. These results confirm previous evidence of significant distortions in the commercial loan market created by lack of bank competition obtained by using different empirical strategies to my own (see, for example, Rice and Strahan (2010), Zarutskie (2006) or Cetorelli and Strahan (2006)). But also underscore the issue that different firms are affected by the structure of banking markets differently. From a methodological point of view, this paper identifies an innovative control group of firms that can be used to perform tests of the effect of bank market structure. This control group could be specially useful in cross-border studies, in which wether a firm operates within a single country or internationally can be easily observable.

Concerning the analysis of banking market structure, I advance the notion that we should redefine the concept of relevant banking market. Currently, academics and regulators have set banking market boundaries geographically, at the level of the county or metropolitan statistical area (MSA). This purely location based approach is problematic, because it overlooks a key fact of the commercial lending market: firms compete with one another across areas of bank influence, and the rate at which a given firm can secure capital affects its ability to compete in the industrial 
marketplace, and ultimately, its ability to repay its loans. Thus, firms with access to competitive financing can charge low industrial prices that must be matched by their competitors located in areas where banks have significant market power, leaving little or no surplus for the oligopolistic banks to extract.

A better definition of relevan banking market needs to take into account the vertical relationship that exists between the banking and other industries. This has already been pointed out in the context of investment banking by Asker and Ljungqvist (2010). In this paper we extend this approach to the commercial lending market. The assumption underlying my analysis is that all businesses with wide geographical span are independent of each other, but a more detailed analysis of information spillovers between industries could probably determine a more nuanced characterization of lending markets that has both geographical dimension and an industrial/product dimension.

In terms of antitrust policy, I show, both conceptually and empirically, the difficulty of sustaining market power in the financial markets without some related kind of market power present in industrial markets. It is clear from the definition of economic market for commercial lending presented here that a little financial competition can spread very quickly amongst geographically interconnected and competitive industries. And the results of these empirical tests support the hypothesis that there is no significant pricing difference in loans to firms in interconnected industrial markets regardless of the level of bank competition they are exposed to in their local markets.

However, this paper also raises an economic policy concern that was missing in previous discussions of bank competition. If the effect identified here is strong enough to be measured empirically, then lack of bank competition may not only generate distortions in the loan market, but in the industrial market as well, potentially leading to collusive pricing and loss of welfare for consumers. Having no competitor outside of the oligopolistic bank's reach, there is no industrial limit to the bank's market power, which is equal to the full monopoly rent in the industrial market. Thus, there is a strong incentive for oligopolistic financial institutions to enforce collusive pricing in the industrial (downstream) sector by setting high interest rates across the industry. Furthermore, the 
fact that locally oligopolistic banks are the only lenders to an entire local industry makes it very difficult for potential "long range" competitor financiers to inform themselves properly about the risks of firms that operate only within the local banking market and therefore face large potential winners' curse. ${ }^{23}$ As we can see, oligopolistic banks have both the incentive to act as collusive devices for the local industrial markets and the ability to erect credible barriers to forestall entry by other financiers to support this outcome. Although I find evidence that firms whose markets all lie within areas where banking competition is limited are being overcharged, at this point only conceptual conjectures can be made as to the effects on local industrial markets. Testing whether these firms charge prices closer to the collusive equilibrium than to the competitive level I believe is an interesting area for further research.

The second main area open to further research is the precise nature of the barrier to competition from out of town banks that allows overcharging. The conceptual framework I propose in this paper cannot answer the question of the relative importance of the many theoretical effects that can determine the interrelation between competition in the product and financial industries. In particular, it would be interesting to further analyze whether issues of firm quality or character (and therefore relationship banking) or issues of industry risk analysis (and therefore bank specialization) have a larger impact on interest rates.

\footnotetext{
${ }^{23}$ If one is to look at the problem of entry into an oligopolistic banking market, it is easy to see (as, for example, in Van Tassel (2006)) that, as long as there is underlying variation in the quality of entrepreneurs and banks learn about this quality by lending to them, incumbent banks will always have an advantage over foreign banks in lending to incumbent industrialists. The newcomer suffers from a winners' curse in that it is only able to lure clients away from informed "relationship bankers" by offering them rates well below their risk adjusted expected return, otherwise the incumbent bank can always match any offer made by the new entrant.
} 


\section{REFERENCES}

Asker, John, and Alexander Ljungqvist, 2010, Competition and the structure of vertical relationships in capital markets, Journal of Political Economy 118, 599-647.

Bain, J. S., 1949, A note on pricing in monopoly and oligopoly, American Economic Review 39, 448-464.

Berger, Allen N., Rebecca S. Demsetz, and Phillip E. Strahan, 1999, The consolidation of the financial services industry: causes, consequences, and implications for the future, Journal of Banking and Finance 50, 187-229.

Berger, Allen N., A. Saunders, J. Scalise, and G. Udell, 1998, The effects of bank mergers and acquisitions on small business lending, Journal of Financial Economics 23, 135-194.

Berger, Allen N., and Gregory F. Udell, 1995, Relationship lending and lines of credit in small firm finance, Journal of Business 68, 351-382.

Black, Sandra, and Philip E. Strahan, 2002, Entrepreneurship and bank credit availability, Journal of Finance 57, 2807-2833.

Boot, Arnoud W. A., 2000, Relationship banking: What do we know?, Journal of Financial Intermediation $9,7-25$.

Boot, Arnoud W. A., and A.V. Thakor, 2000, Can relationship banking survive competition?, Journal of Finance 679-713.

Boyd, John H., and Gianni De Nicoló, 2005, The theory of bank risk taking and competition revisited, Journal of Finance 60, 1329-1343.

Bresnahan, T. F., 1982, The oligopoly solution concept is identified, Economics Letters 10, 87-92.

Cetorelli, N., and Philip E. Strahan, 2006, Finance as a barrier to entry: Bank competition and industry structure in local US markets, The Journal of Finance 61, 437-461.

Cole, Rebel A., John D. Wolken, and R. Louise Woodburn, 1996, Bank and nonbank competition for small business credit: Evidence from the 1987 and 1993 national surveys of small business finances, Federal Reserve Bulletin 82, 983-995.

Craig, Steven G., and Pauline Hardee, 2007, The impact of bank consolidation on small business credit availability, Journal of Banking 8 Finance 31, 1237-1263.

Degryse, Hans, and Patrick Van Cayseele, 2000, Relationship lending within a bank-based system: Evidence from European small business data, Journal of Financial Intermediation 9, 90-109.

Guiso, L., P. Sapienza, and Luigi Zingales,2004, Does local financial development matter?, The Quarterly Journal of Economics 119, 929-969. 
Gilbert, R.A., 1984, Bank market structure and competition: A survey, Journal of Money, Credit and Banking 16, 617-645.

Hale, G., and J.A.C. Santos, 2009, Do banks price their informational monopoly?, Journal of Financial Economics 93, 185-206.

Hannan, T.H., 1991, Bank commercial loan markets and the role of market structure: Evidence from surveys of commercial lending, Journal of Banking $\&$ Finance 15, 133-149.

Jayaratne, Jith, and Philip E. Strahan, 1996, The finance-growth nexus: Evidence from bank branch deregulation, Quarterly Journal of Economics 111, 639-670.

Kerr, William, and Ramana Nanda, 2009, Democratizing entry: Banking deregulation, financing constraints, and entrepreneurship, Journal of Financial Economics 94.

King, R., and R. Levine, 1993, Finance and growth: Schumpeter might be right, Quarterly Journal of Economics 108, 717-737.

Levine, Ross, Norman Loayza, and Thorsten Beck, 2000, Financial intermediation and growth: causality and causes, Journal of Monetary Economics 46, 31-77.

Martinez Miera, David, and Rafael Repullo, 2010, Does competition reduce the risk of bank failure?, Review of Financial Studies 23, 3638-3664.

Meyer, Bruce D, 1995, Natural and quasi-experiments in economics, Journal of Business 8 Economic Statistics 13, 151-161.

Petersen, M.A., and Raghuram G. Rajan, 1994, The benefits of lending relationships: Evidence from small business data, Journal of Finance 49, 3-37.

Petersen, M.A., and Raghuram G. Rajan, 1995, The effect of credit market competition on lending relationships, The Quarterly Journal of Economics 110, 407-443.

Rajan, Raghuram G., 1992, Insiders and outsiders: The choice between informed and arm's-length debt, Journal of finance 1367-1400.

Rajan, Raghuram G., and Luigi Zingales, 1998, Financial dependence and growth, American Economic Review 88, 559-586.

Rice, T., and Philip E. Strahan, 2010, Does credit competition affect small-firm finance?, The Journal of Finance 65, 861-889.

Rosse, J. N., and John C. Panzar, 1977, Chamberlain vs. Robinson: An empirical study for monopoly rents, Bell Laboratories Economic Discussion Paper.

Sapienza, P., 2002, The effects of banking mergers on loan contracts, Journal of Finance 57, 329367. 
Schumpeter, J., 1912, The theory of economic development, (Cambridge, MA: Harvard University Press)

Sengupta, R., 2007, Foreign entry and bank competition, Journal of Financial Economics 84, $502-528$.

Shaffer, Sherill, 2004, Patterns of competition in banking, Journal of Economics $\&$ Business 56, $287-313$.

Van Tassel, Eric, 2006, Relationship lending under asymmetric information: a case of blockaded entry, International Journal of Industrial Organization 24, 915-929.

Weiss, L. W., 1989, Concentration and price, chapter A review of concentration-price studies in banking, 219-254 (Cambridge, MA: MIT Press).

Zarutskie, Rebecca, 2006, Evidence on the effects of bank competition on firm borrowing and investment, Journal of Financial Economics 81, 503-537. 
Town A

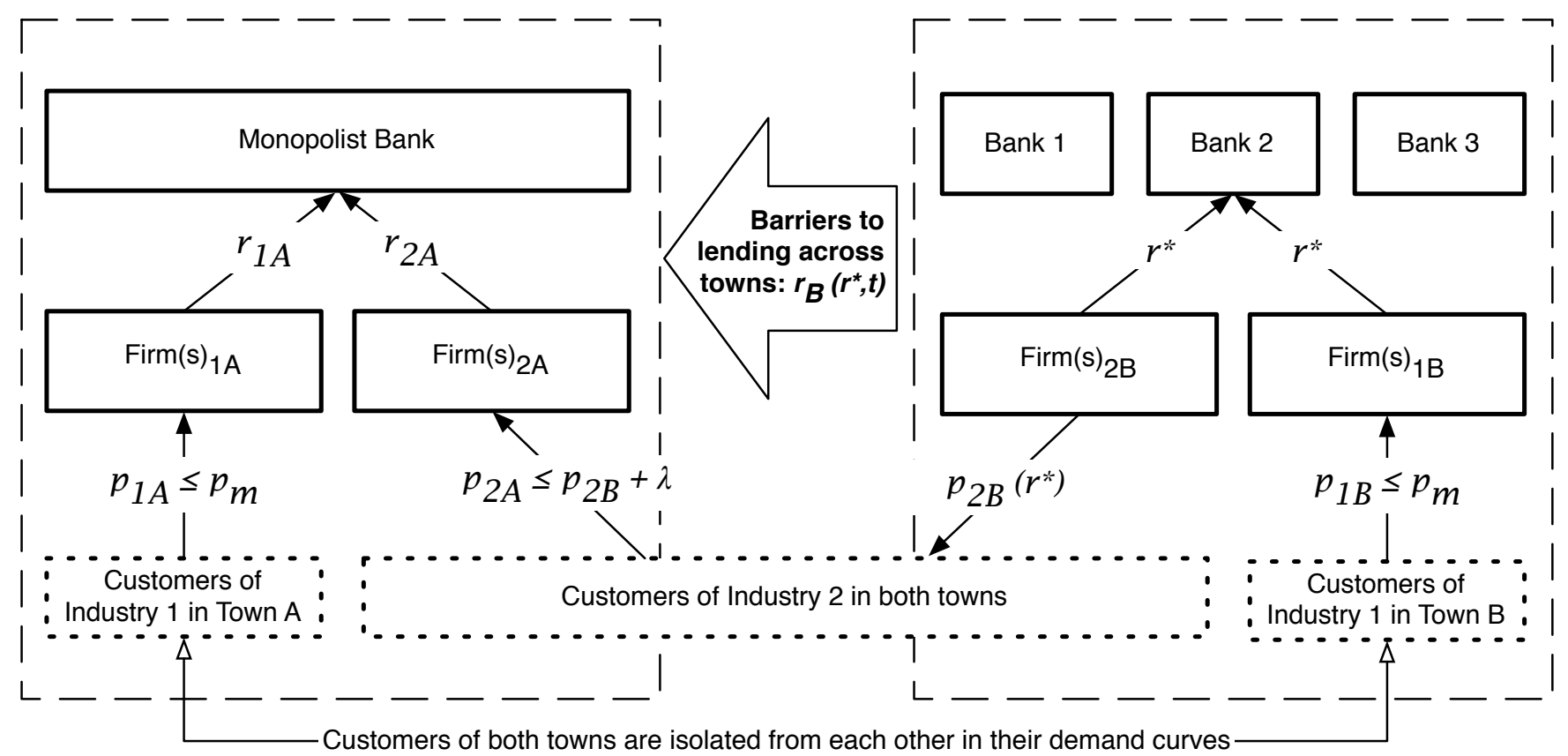

Figure 1. Structure of model: geographical and industrial limits to a bank's market power. This figure plots the main drivers of a bank's limits to how much surplus it can extract from its customers for two kinds of industries. Firms that belong to industry 1 sell products that can only be consumed in the location where they are produced, and therefore face very little competition from "out of town" industrial competitors. On the other hand, firms in industry 2 are part of an interconnected marketplace. 


\section{Table I. Size of subpopulations}

This table shows both the number of observations from the data of the Survey of Small Business Finances (SSBF) and the percentage of the target population of small firms they represent, that fit into each of the four groups defined in the Section III to perform a difference-in-differences test of the effect of banking market power on interest rates.

\begin{tabular}{|c|c|c|c|c|}
\hline & \multicolumn{2}{|c|}{$\begin{array}{c}\text { Oligopolistic } \\
\text { banking markets }\end{array}$} & \multicolumn{2}{|c|}{$\begin{array}{c}\text { Competitive } \\
\text { banking markets }\end{array}$} \\
\hline & $\begin{array}{l}\text { Firms in single } \\
\text { banking market }\end{array}$ & $\begin{array}{c}\text { Firms in many } \\
\text { banking markets }\end{array}$ & $\begin{array}{l}\text { Firms in single } \\
\text { banking market }\end{array}$ & $\begin{array}{l}\text { Firms in many } \\
\text { banking markets }\end{array}$ \\
\hline \multicolumn{5}{|c|}{ Number of observations } \\
\hline All respondents & 996 & 1,075 & 1,099 & 1,064 \\
\hline Recent loans & 313 & 468 & 386 & 485 \\
\hline \multicolumn{5}{|c|}{ Percentage of target population } \\
\hline All respondents & 25.8 & 22.2 & 29.4 & 22.7 \\
\hline Recent loans & 23.1 & 23.5 & 29.1 & 24.3 \\
\hline
\end{tabular}


Table II. Summary description of the data

This table shows the distribution of key characteristics for the observations pertaining each of the four groups defined in the Section III to perform a difference-in-differences test of the effect of banking market power on interest rates.

\begin{tabular}{|c|c|c|c|c|c|c|c|c|}
\hline & \multicolumn{4}{|c|}{$\begin{array}{c}\text { Oligopolistic } \\
\text { banking markets }\end{array}$} & \multicolumn{4}{|c|}{$\begin{array}{c}\text { Competitive } \\
\text { banking markets }\end{array}$} \\
\hline & \multicolumn{2}{|c|}{$\begin{array}{l}\text { Firms in single } \\
\text { banking market }\end{array}$} & \multicolumn{2}{|c|}{$\begin{array}{c}\text { Firms in many } \\
\text { banking markets }\end{array}$} & \multicolumn{2}{|c|}{$\begin{array}{l}\text { Firms in single } \\
\text { banking market }\end{array}$} & \multicolumn{2}{|c|}{$\begin{array}{l}\text { Firms in many } \\
\text { banking markets }\end{array}$} \\
\hline & Mean & Stdev. & Mean & Stdev. & Mean & Stdev. & Mean & Stdev. \\
\hline \multicolumn{9}{|c|}{ Panel A: Firm characteristics } \\
\hline Assets (\$'000) & & & & & & & & \\
\hline All respondents & 357 & 54 & 707 & 65 & 364 & 29 & 789 & 73 \\
\hline Recent loans & 732 & 176 & 1,452 & 167 & 637 & 76 & 1,773 & 209 \\
\hline \multicolumn{9}{|c|}{ Percentage of firms with sales growing or stable over 3 yrs } \\
\hline All respondents & 59.5 & 2.0 & 56.0 & 2.0 & 60.0 & 1.9 & 54.1 & 2.1 \\
\hline Recent loans & 61.2 & 3.9 & 61.2 & 3.7 & 68.3 & 3.5 & 57.4 & 3.5 \\
\hline \multicolumn{9}{|l|}{ Firm age (years) } \\
\hline All respondents & 14.5 & 0.45 & 14.7 & 0.46 & 14.4 & 0.43 & 13.6 & 0.43 \\
\hline Recent loans & 15.4 & 0.91 & 15.3 & 0.78 & 14.8 & 0.79 & 15.5 & 0.74 \\
\hline \multicolumn{9}{|c|}{ Firm leverage (total debt as a percentage of book value of assets) } \\
\hline All respondents & 95.7 & 41.6 & 176.7 & $86.3^{\circ}$ & 79.8 & 11.3 & 178.0 & 50.2 \\
\hline Recent loans & 51.9 & 4.2 & 96.5 & 35.8 & 103.3 & 15.6 & 90.0 & 24.5 \\
\hline \multicolumn{9}{|c|}{ Percentage of firms in an urban location } \\
\hline All respondents & 62.0 & 1.7 & 66.8 & 1.8 & 92.9 & 0.9 & 93.9 & 1.2 \\
\hline Recent loans & 52.1 & 3.9 & 61.3 & 3.6 & 88.9 & 2.2 & 89.0 & 3.1 \\
\hline \multicolumn{9}{|c|}{ Panel B: Access to finance (\% of firms) } \\
\hline Rejected loan & 5.4 & 0.9 & 4.6 & 0.8 & 4.0 & 0.7 & 6.6 & 1.1 \\
\hline New equity & 4.1 & 0.8 & 5.8 & 1.0 & 5.5 & 0.9 & 7.2 & 1.1 \\
\hline Demanded funds & 44.7 & 2.0 & 47.9 & 2.1 & 44.7 & 1.9 & 52.0 & 2.1 \\
\hline Demanded debt & 42.9 & 2.0 & 45.4 & 2.1 & 41.1 & 1.9 & 49.4 & 2.1 \\
\hline \multicolumn{9}{|c|}{ Panel C: Loan characteristics } \\
\hline Interest $(\%)$ & 6.99 & 0.30 & 6.50 & 0.24 & 6.48 & 0.31 & 6.32 & 0.20 \\
\hline Spread (\%) & 2.55 & 0.30 & 2.00 & 0.26 & 1.98 & 0.33 & 1.96 & 0.20 \\
\hline Fees $(\%)$ & 0.7 & 0.1 & 1.0 & 0.2 & 1.5 & 0.4 & 1.1 & 0.3 \\
\hline Amount $(\$ ' 000)$ & 195 & 54 & 335 & 44 & 232 & 40 & 557 & 90 \\
\hline
\end{tabular}




\begin{tabular}{|c|c|c|c|c|c|c|c|c|}
\hline & \multicolumn{4}{|c|}{$\begin{array}{c}\text { Oligopolistic } \\
\text { banking markets }\end{array}$} & \multicolumn{4}{|c|}{$\begin{array}{c}\text { Competitive } \\
\text { banking markets }\end{array}$} \\
\hline & \multicolumn{2}{|c|}{$\begin{array}{l}\text { Firms in single } \\
\text { banking market }\end{array}$} & \multicolumn{2}{|c|}{$\begin{array}{c}\text { Firms in many } \\
\text { banking markets }\end{array}$} & \multicolumn{2}{|c|}{$\begin{array}{l}\text { Firms in single } \\
\text { banking market }\end{array}$} & \multicolumn{2}{|c|}{$\begin{array}{l}\text { Firms in many } \\
\text { banking markets }\end{array}$} \\
\hline & Mean & Stdev. & Mean & Stdev. & Mean & Stdev. & Mean & Stdev. \\
\hline \multicolumn{9}{|c|}{ (Continued from previous page) } \\
\hline Maturity (months) & 55.8 & 5.5 & 53.1 & 6.9 & 59.7 & 5.8 & 41.5 & 4.9 \\
\hline \multicolumn{9}{|c|}{ Percentage of loan population that is: } \\
\hline Long term & 61.6 & 3.9 & 59.0 & 3.6 & 62.4 & 3.5 & 49.1 & 3.7 \\
\hline Line of credit & 48.9 & 4.0 & 61.0 & 3.7 & 61.4 & 3.7 & 70.8 & 3.3 \\
\hline Secured & 74.2 & 3.7 & 78.7 & 3.2 & 70.6 & 3.4 & 84.2 & 2.6 \\
\hline Fixed rate & 57.0 & 3.9 & 57.5 & 3.6 & 56.2 & 3.7 & 46.7 & 3.7 \\
\hline
\end{tabular}




\section{Table III. Model specification and estimation}

This table reports the coefficients of several regressions of the interest rate spread of a firm's most recently approved loan on bank concentration and other borrower, loan and environmental characteristics, for both the "treatment" (firms that operate within a single banking market) and "control" groups (firms that operate across wider geographical areas). Several alternative specifications of the difference-in-differences test are shown using different sets of covariates provided by the previous literature. Model I is my base model, Model II is a more parsimonious specification without loan characteristics as regressors, Model III follows the specification of Rice and Strahan (2010), Model IV follows Petersen and Rajan (1994), and Model V follows Petersen and Rajan (1995). Absolute values of unadjusted t-statistics are in parentheses, where significance after error clustering is indicated by ${ }^{*}$ at the $10 \%$ level, ${ }^{* *}$ at the $5 \%$ level and ${ }^{* * *}$ at the $1 \%$ level.

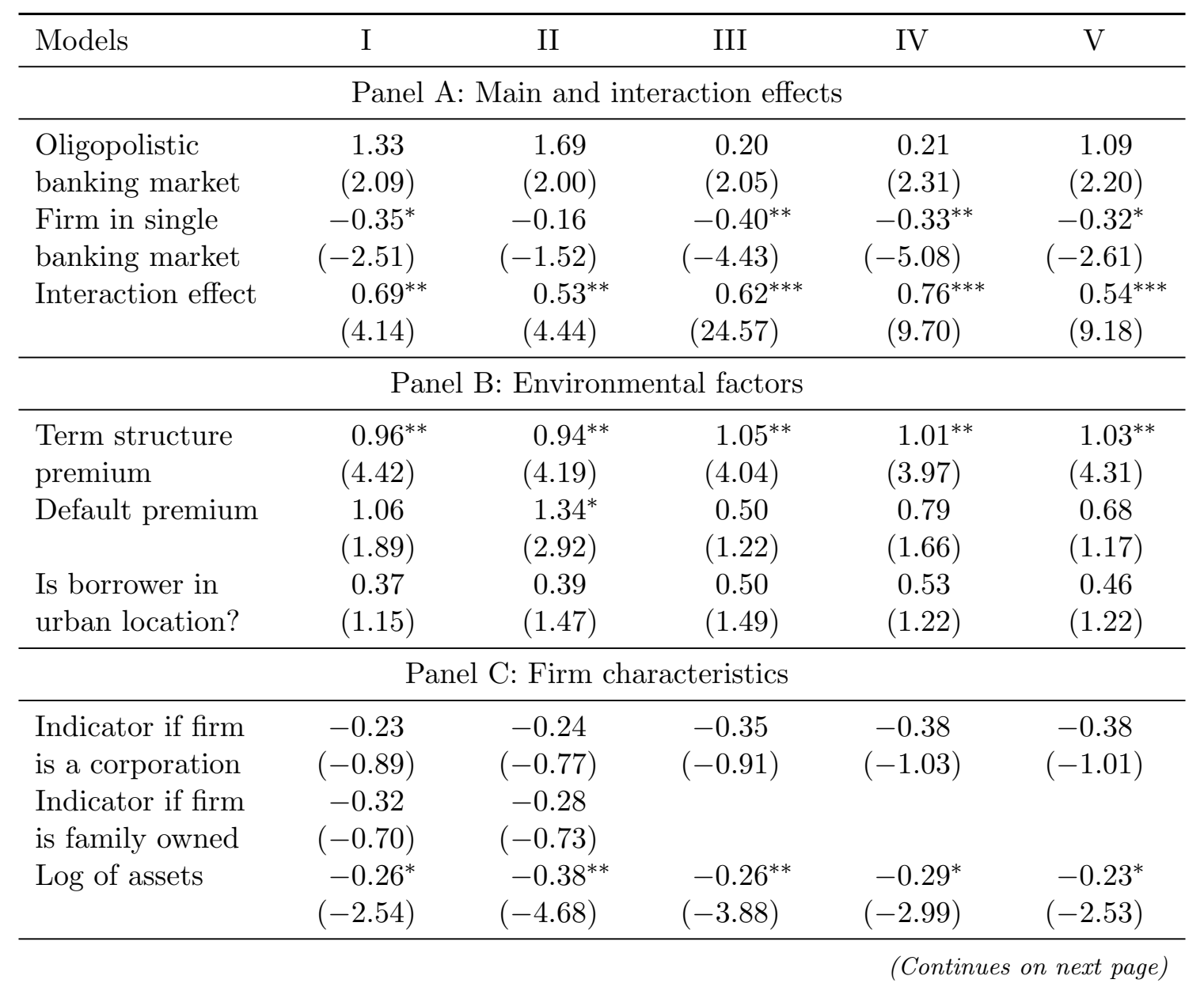




\begin{tabular}{|c|c|c|c|c|c|}
\hline Models & $\mathrm{I}$ & II & III & IV & $\mathrm{V}$ \\
\hline \multicolumn{6}{|c|}{ (Continued from previous page) } \\
\hline $\begin{array}{l}\text { Number of } \\
\text { employees }\end{array}$ & $\begin{array}{l}-0.00 \\
(-1.61)\end{array}$ & $\begin{array}{c}-0.00 \\
(-2.00)\end{array}$ & & & \\
\hline Indicator if sales & 0.16 & 0.09 & & 0.11 & \\
\hline are stable & $(0.32)$ & $(0.17)$ & & $(0.21)$ & \\
\hline $\begin{array}{l}\text { Indicator if sales } \\
\text { are growing }\end{array}$ & $\begin{array}{l}0.34^{* *} \\
(3.80)\end{array}$ & $\begin{array}{c}0.18 \\
(0.95)\end{array}$ & & $\begin{array}{c}0.19 \\
(1.93)\end{array}$ & \\
\hline Leverage & $\begin{array}{l}0.02 \\
(0.55)\end{array}$ & $\begin{array}{c}-0.01 \\
(-0.35)\end{array}$ & & & $\begin{array}{c}0.00 \\
(0.07)\end{array}$ \\
\hline $\begin{array}{l}\text { Total debt } \\
(\$ \mathrm{mn})\end{array}$ & & & & $\begin{array}{c}0.04 \\
(0.22)\end{array}$ & \\
\hline EBIT Margin & $\begin{array}{l}-0.45 \\
(-1.62)\end{array}$ & $\begin{array}{l}-0.37 \\
(-1.23)\end{array}$ & & $\begin{array}{l}-0.22 \\
(-0.77)\end{array}$ & \\
\hline $\begin{array}{l}\text { Margin relative } \\
\text { to peers }\end{array}$ & $\begin{array}{c}0.01 \\
(1.25)\end{array}$ & $\begin{array}{c}0.01 \\
(1.27)\end{array}$ & & & \\
\hline $\mathrm{ROA}$ & $\begin{array}{c}-0.01 \\
(-0.45)\end{array}$ & $\begin{array}{c}0.01 \\
(0.56)\end{array}$ & $\begin{array}{c}-0.01 \\
(-0.48)\end{array}$ & & \\
\hline Turnover & $\begin{array}{c}-0.01 \\
(-2.20)\end{array}$ & $\begin{array}{l}-0.02^{* *} \\
(-3.31)\end{array}$ & & & \\
\hline $\begin{array}{l}\text { Firm Age } \\
\text { (years) }\end{array}$ & $\begin{array}{l}-0.02 \\
(-0.72)\end{array}$ & $\begin{array}{l}-0.01 \\
(-0.75)\end{array}$ & $\begin{array}{l}-0.02^{* *} \\
(-3.26)\end{array}$ & $\begin{array}{l}-0.02^{*} \\
(-2.78)\end{array}$ & \\
\hline $\begin{array}{l}\text { Log(age) if } \\
\text { competitive }\end{array}$ & $\begin{array}{c}0.22 \\
(1.32)\end{array}$ & $\begin{array}{c}0.30 \\
(1.41)\end{array}$ & & & $\begin{array}{l}-0.09 \\
(-1.99)\end{array}$ \\
\hline $\begin{array}{l}\log (\text { age }) \text { if } \\
\text { concentrated }\end{array}$ & $\begin{array}{c}-0.19 \\
(-0.53)\end{array}$ & $\begin{array}{c}-0.20 \\
(-0.49)\end{array}$ & & & $\begin{array}{l}-0.44^{*} \\
(-2.37)\end{array}$ \\
\hline \multicolumn{6}{|c|}{ Panel D: Relationship characteristics } \\
\hline $\begin{array}{l}\text { Number of } \\
\text { relationships }\end{array}$ & $\begin{array}{c}0.03 \\
(0.23)\end{array}$ & $\begin{array}{c}0.04 \\
(0.43)\end{array}$ & $\begin{array}{c}0.13 \\
(0.99)\end{array}$ & & \\
\hline $\begin{array}{l}\text { Number of } \\
\text { lenders }\end{array}$ & $\begin{array}{c}0.08 \\
(0.81)\end{array}$ & $\begin{array}{c}0.03 \\
(0.31)\end{array}$ & & $\begin{array}{c}0.13 \\
(1.06)\end{array}$ & $\begin{array}{c}0.13 \\
(0.89)\end{array}$ \\
\hline Relationship & 0.01 & 0.02 & 0.01 & 0.01 & 0.01 \\
\hline length (yrs) & $(0.63)$ & $(1.01)$ & $(1.55)$ & $(2.10)$ & $(1.33)$ \\
\hline Is lender & $0.43^{* *}$ & 0.21 & & & \\
\hline $\begin{array}{l}\text { primary inst.? } \\
\text { Longest (yrs) }\end{array}$ & $\begin{array}{c}(5.13) \\
-0.00\end{array}$ & $\begin{array}{c}(1.10) \\
-0.00\end{array}$ & & & \\
\hline relationship & $(-0.05)$ & $(-0.22)$ & & & \\
\hline Furthest (mi) & 0.00 & $0.00^{* * *}$ & & & \\
\hline relationship & $(0.92)$ & $(6.07)$ & & & \\
\hline Was borrower & 1.73 & 1.32 & & & \\
\hline
\end{tabular}

(Continues on next page) 


\begin{tabular}{|c|c|c|c|c|c|}
\hline Models & $\mathrm{I}$ & II & III & IV & $\mathrm{V}$ \\
\hline \multicolumn{6}{|c|}{ (Continued from previous page) } \\
\hline denied credit? & $(1.47)$ & $(1.03)$ & & & \\
\hline Did borrower & 0.58 & 0.53 & & & \\
\hline fear denial? & $(1.00)$ & $(1.17)$ & & & \\
\hline Times applied & -0.03 & -0.03 & & & \\
\hline for a loan & $(-0.52)$ & $(-1.35)$ & & & \\
\hline $\begin{array}{l}\text { Number of } \\
\text { renewals }\end{array}$ & $\begin{array}{c}0.07 \\
(1.78)\end{array}$ & $\begin{array}{c}0.12^{*} \\
(2.90)\end{array}$ & & & \\
\hline Deposits & $\begin{array}{c}-0.34 \\
(-1.27)\end{array}$ & $\begin{array}{c}-0.30 \\
(-0.81)\end{array}$ & $\begin{array}{c}-0.44 \\
(-1.41)\end{array}$ & $\begin{array}{c}-0.45 \\
(-1.35)\end{array}$ & $\begin{array}{c}-0.41 \\
(-1.59)\end{array}$ \\
\hline Information & -0.23 & -0.59 & -0.43 & -0.45 & -0.41 \\
\hline services & $(-1.07)$ & $(-1.67)$ & $(-1.31)$ & $(-1.03)$ & $(-1.36)$ \\
\hline No-information & 0.22 & 0.41 & $0.80^{* *}$ & $0.73^{* *}$ & $0.69^{* * *}$ \\
\hline services & $(1.18)$ & $(1.66)$ & $(4.37)$ & $(4.14)$ & $(6.62)$ \\
\hline \multicolumn{6}{|c|}{ Panel E: Loan characteristics } \\
\hline Non-bank & $2.83^{* *}$ & $3.31^{* *}$ & $3.24^{* *}$ & $3.19^{*}$ & $3.30^{* *}$ \\
\hline Lender & $(3.24)$ & $(3.85)$ & $(3.25)$ & $(3.01)$ & $(3.62)$ \\
\hline Non-financial & -0.80 & -0.33 & -0.81 & -0.78 & -0.72 \\
\hline Lender & $(-0.86)$ & $(-0.47)$ & $(-0.59)$ & $(-0.88)$ & $(-0.58)$ \\
\hline Is rate & $1.54^{* * *}$ & & $1.41^{* * *}$ & $1.39^{* * *}$ & $1.42^{* * *}$ \\
\hline fixed? & $(9.05)$ & & $(18.35)$ & $(9.19)$ & $(13.06)$ \\
\hline Is loan a & $0.58^{*}$ & & & & \\
\hline renewal? & $(2.40)$ & & & & \\
\hline Is loan & $-1.21^{* *}$ & & & & \\
\hline secured? & $(-5.18)$ & & & & \\
\hline \multicolumn{6}{|c|}{ Panel F: Fixed effect dummy variables } \\
\hline SIC codes $(9)$ & yes & yes & yes & yes & yes \\
\hline Division (9) & yes & yes & yes & yes & yes \\
\hline D\&B scores $(5)$ & yes & yes & yes & no & yes \\
\hline Collateral (7) & yes & no & no & no & yes \\
\hline Loan type (6) & yes & no & no & no & no \\
\hline Observations & 1311 & 1320 & 1375 & 1338 & 1402 \\
\hline
\end{tabular}


Table IV. Non-parametrical tests of the effect of firm characteristics

This table reports the main and interaction effects of several regressions of interest rate spreads on bank concentration, geographical spread of firm competition and a vector of control variables described in Section IV.B. The first column shows results for the full sample, the second restricts the sample to those firms located in urban areas, the third and fourth columns report the results of fitting the model independently for small and large firms (defined based on median assets). Absolute values of unadjusted t-statistics are in parentheses, where significance after error clustering is indicated by ${ }^{*}$ at the $10 \%$ level, ${ }^{* *}$ at the $5 \%$ level and ${ }^{* * *}$ at the $1 \%$ level.

\begin{tabular}{lcccc}
\hline & & & \multicolumn{2}{c}{ Firm Assets } \\
\cline { 5 - 5 } Models & Full & Urban & Large & Small \\
\hline Main effect of oligopolistic & 1.33 & $2.09^{*}$ & $1.73^{* *}$ & 1.39 \\
banking market & $(2.09)$ & $(2.44)$ & $(4.69)$ & $(2.31)$ \\
Main effect of firm in & $-0.35^{*}$ & $-0.38^{* *}$ & 0.02 & $-0.47^{*}$ \\
single banking market & $(-2.51)$ & $(-3.44)$ & $(0.13)$ & $(-2.91)$ \\
Interaction effect & $0.69^{* *}$ & $1.23^{* *}$ & $0.62^{* * *}$ & $0.95^{* *}$ \\
& $(4.14)$ & $(4.15)$ & $(6.06)$ & $(3.96)$ \\
\hline Observations & 1311 & 1012 & 661 & 650 \\
$R^{2}$ & 0.561 & 0.581 & 0.576 & 0.597 \\
\hline
\end{tabular}


Table V. Industry distribution among subpopulations

This table reports what percentage of our population of interest (firms with recently approved arms' length loans) falls into each broad business category for each of the subgroups defined in Section III in order to perform a difference-in-differences test of the effect of banking market power on interest rates.

\begin{tabular}{lccccc}
\hline & \multicolumn{2}{c}{$\begin{array}{c}\text { Oligopolistic } \\
\text { banking markets }\end{array}$} & & \multicolumn{2}{c}{$\begin{array}{c}\text { Competitive } \\
\text { banking markets }\end{array}$} \\
\cline { 2 - 3 } \cline { 5 - 6 } & $\begin{array}{c}\text { Firms in single } \\
\text { banking market }\end{array}$ & $\begin{array}{c}\text { Firms in many } \\
\text { banking markets }\end{array}$ & $\begin{array}{c}\text { Firms in single } \\
\text { banking market }\end{array}$ & $\begin{array}{c}\text { Firms in many } \\
\text { banking markets }\end{array}$ \\
\hline Mining & - & 0.48 & & - & 0.32 \\
Construction & 3.72 & 2.74 & & 4.19 & 3.33 \\
Manufacturing & 0.07 & 3.99 & & 1.07 & 3.95 \\
Transport & & & & 0.48 & 1.22 \\
\& Utilities & 0.43 & 2.09 & & 0.07 & 3.07 \\
Wholesale & 1.04 & 2.75 & & 6.03 & 2.78 \\
Retail & 7.36 & 2.52 & & 1.92 & 1.06 \\
Finance & & & & 14.69 & 8.58 \\
\& Real Estate & 1.36 & 6.03 & & \\
Services & 8.48 & 60 & & & \\
\hline
\end{tabular}


Table VI. Non-parametrical tests of the effect of industrial sector

This table reports the main and interaction effects of several regressions of interest rate spreads on bank concentration, geographical spread of firm competition and a vector of control variables described in Section IV.B. The first column shows results for the full sample, the second is the result of restricting the sample to firms in heavy industries (mining, construction, transportation, utilities and wholesale). The third column shows the results of fitting the model for all other firms. Absolute values of unadjusted t-statistics are in parentheses, where significance after error clustering is indicated by ${ }^{*}$ at the $10 \%$ level, ${ }^{* *}$ at the $5 \%$ level and ${ }^{* * *}$ at the $1 \%$ level.

\begin{tabular}{lccc}
\hline Models & Full & Heavy Industry & Other \\
\hline Main effect of oligopolistic & 1.33 & 0.72 & 1.19 \\
banking market & $(2.09)$ & $(0.68)$ & $(1.45)$ \\
Main effect of firm & $-0.35^{*}$ & $-0.76^{* * *}$ & -0.31 \\
in single banking market & $(-2.51)$ & $(-6.87)$ & $(-1.70)$ \\
Interaction effect & $0.69^{* *}$ & $1.52^{* *}$ & $0.65^{*}$ \\
& $(4.14)$ & $(4.54)$ & $(2.50)$ \\
\hline Observations & 1311 & 416 & 895 \\
$R^{2}$ & 0.561 & 0.632 & 0.553 \\
\hline
\end{tabular}


Table VII. Non-parametrical tests of the effect of loan characteristics

This table reports the main and interaction effects of several regressions of interest rate spreads on bank concentration, geographical spread of firm competition and a vector of control variables described in Section IV.B. The first column shows results for the full sample, the second restricts the sample to those firms whose most recently approved (MRA) loan is a line of credit, while the third column reports results for all other firms. Column four and five show the results of independently fitting the model to firms whose MRA loan has a maturity of more than 12 months (long term) or less (short term). Absolute values of unadjusted t-statistics are in parentheses, where significance after error clustering is indicated by ${ }^{*}$ at the $10 \%$ level, ${ }^{* *}$ at the $5 \%$ level and ${ }^{* * *}$ at the $1 \%$ level.

\begin{tabular}{|c|c|c|c|c|c|}
\hline \multirow[b]{2}{*}{ Models } & \multirow[b]{2}{*}{ Full } & \multicolumn{2}{|c|}{ Type of loan } & \multicolumn{2}{|c|}{ Maturity } \\
\hline & & Line of Credit & Other & Short & Long \\
\hline Main effect of oligopolistic & 1.33 & 1.30 & 0.35 & $2.31^{* *}$ & 0.94 \\
\hline banking market & $(2.09)$ & $(1.35)$ & $(0.66)$ & $(3.94)$ & $(1.55)$ \\
\hline Main effect of firm in & $-0.35^{*}$ & $-0.35^{* *}$ & -0.48 & $-0.84^{*}$ & 0.02 \\
\hline single banking market & $(-2.51)$ & $(-4.16)$ & $(-1.57)$ & $(-2.36)$ & $(0.14)$ \\
\hline \multirow[t]{2}{*}{ Interaction effect } & $0.69^{* *}$ & $0.29^{* *}$ & $1.20^{* *}$ & $1.27^{* *}$ & $0.46^{*}$ \\
\hline & $(4.14)$ & $(5.02)$ & $(3.26)$ & $(5.82)$ & $(3.12)$ \\
\hline Observations & 1311 & 850 & 461 & 622 & 689 \\
\hline$R^{2}$ & 0.561 & 0.614 & 0.647 & 0.550 & 0.672 \\
\hline
\end{tabular}


Table VIII. Distribution of credit ratings

This table shows the distribution of the Dun \& Bradstreet credit score amongst observations in each of the four groups defined in the Section III to perform a difference-in-differences test of the effect of banking market power on interest rates.

\begin{tabular}{|c|c|c|c|c|c|c|c|c|}
\hline & \multicolumn{4}{|c|}{$\begin{array}{c}\text { Oligopolistic } \\
\text { banking markets }\end{array}$} & \multicolumn{4}{|c|}{$\begin{array}{c}\text { Competitive } \\
\text { banking markets }\end{array}$} \\
\hline & \multicolumn{2}{|c|}{$\begin{array}{l}\text { Firms in single } \\
\text { banking market }\end{array}$} & \multicolumn{2}{|c|}{$\begin{array}{c}\text { Firms in many } \\
\text { banking markets }\end{array}$} & \multicolumn{2}{|c|}{$\begin{array}{l}\text { Firms in single } \\
\text { banking market }\end{array}$} & \multicolumn{2}{|c|}{$\begin{array}{l}\text { Firms in many } \\
\text { banking market }\end{array}$} \\
\hline & Mean & Stdev. & Mean & Stdev. & Mean & Stdev. & Mean & Stdev. \\
\hline \multicolumn{9}{|c|}{ Average D\&B credit score } \\
\hline All respondents & 2.79 & 0.04 & 2.97 & 0.05 & 2.85 & 0.04 & 2.77 & 0.05 \\
\hline Recent loans & 2.79 & 0.09 & 3.09 & 0.08 & 2.93 & 0.08 & 2.91 & 0.10 \\
\hline \multicolumn{9}{|c|}{ Percentage of population with safest credit score $=1$} \\
\hline All respondents & 7.8 & 1.2 & 6.4 & 1.0 & 8.6 & 1.2 & 11.6 & 1.5 \\
\hline Recent loans & 11.7 & 2.8 & 4.5 & 1.4 & 5.2 & 1.5 & 13.1 & 3.0 \\
\hline \multicolumn{9}{|c|}{ Percentage of population with credit score $=2$} \\
\hline All respondents & 40.3 & 2.0 & 35.0 & 2.0 & 37.3 & 1.9 & 34.5 & 2.0 \\
\hline Recent loans & 37.9 & 4.0 & 33.3 & 3.7 & 38.6 & 3.9 & 27.6 & 3.1 \\
\hline \multicolumn{9}{|c|}{ Percentage of population with credit score $=3$} \\
\hline All respondents & 25.1 & 1.8 & 24.1 & 1.7 & 24.3 & 1.6 & 25.9 & 1.8 \\
\hline Recent loans & 22.3 & 3.3 & 25.1 & 3.0 & 24.8 & 3.0 & 27.3 & 3.2 \\
\hline \multicolumn{9}{|c|}{ Percentage of population with credit score $=4$} \\
\hline All respondents & 14.7 & 1.4 & 21.9 & 1.7 & 18.4 & 1.4 & 16.6 & 1.4 \\
\hline Recent loans & 15.4 & 2.6 & 22.4 & 3.2 & 19.2 & 2.7 & 17.5 & 2.5 \\
\hline \multicolumn{9}{|c|}{ Percentage of population with riskiest credit score $=5$} \\
\hline All respondents & 10.4 & 1.1 & 11.5 & 1.2 & 10.8 & 1.1 & 9.4 & 1.2 \\
\hline Recent loans & 12.3 & 2.5 & 14.6 & 2.5 & 11.3 & 2.1 & 13.8 & 2.8 \\
\hline
\end{tabular}


Table IX. Non-parametrical tests of the effect of other variables

This table reports the main and interaction effects of several regressions of interest rate spreads on bank concentration, geographical spread of firm competition and a vector of control variables described in Section IV.B. The first column shows results for the full sample, the second restricts the sample to loans originated by banks that are part of a bank holding company, whereas the third column reports the results for all other loans. The fourth and fifth columns show the results of fitting the model independently for firms younger than 16 years (the median firm age) and younger than 9 years respectively. Absolute values of unadjusted t-statistics are in parentheses, where significance after error clustering is indicated by ${ }^{*}$ at the $10 \%$ level, ${ }^{* *}$ at the $5 \%$ level and *** at the $1 \%$ level.

\begin{tabular}{lccccccc}
\hline \multirow{2}{*}{ Models } & & \multicolumn{2}{c}{ Part of a Bank Holding Co } & & \multicolumn{2}{c}{ Firm Age } \\
\cline { 7 - 8 } & Full & Yes & No & & $\leq 16$ yrs & $\leq 9$ yrs \\
\hline Main effect of oligopolistic & 1.33 & $0.91^{*}$ & 1.11 & & 0.39 & -0.04 \\
banking market & $(2.09)$ & $(2.37)$ & & $(0.57)$ & & $(0.96)$ & $(-0.04)$ \\
Main effect of firm & $-0.35^{*}$ & -0.03 & $-2.02^{*}$ & & -0.54 & -0.27 \\
in single banking market & $(-2.51)$ & $(-0.20)$ & & $(-2.78)$ & & $(-1.91)$ & $(-0.66)$ \\
Interaction effect & $0.69^{* *}$ & $0.39^{* *}$ & & $3.33^{* * *}$ & & $1.21^{* *}$ & $1.18^{*}$ \\
& $(4.14)$ & $(3.20)$ & & $(8.63)$ & & $(3.55)$ & $(2.54)$ \\
\hline Observations & 1311 & 1054 & 216 & & 654 & 350 \\
$R^{2}$ & 0.561 & 0.607 & 0.729 & & 0.666 & 0.750 \\
\hline
\end{tabular}

